\title{
Ventilation of horse riding helmets: what is the connection between laboratory and field measurements?
}

\author{
Matthieu Jolly ${ }^{1 *}$, Alexia Cariou1, Emmanuelle Koralewski ${ }^{2}$ \\ From 15th International Conference on Environmental Ergonomics (ICEE XV) \\ Portsmouth, UK. 28 June - 3 July 2015
}

\begin{abstract}
Introduction
Helmets have received little attention in the literature[1] concerning thermal comfort. Whether it is for motorcycling or cycling, ventilation of helmets has become an issue [2,3]. Relationships between heat loss and the effects perceived vary among helmets. Fouganza, the equestrian brand of Decathlon, has made ventilation of horse riding helmets a priority, first laboratory and then field measurements were performed in order to evaluate the validity of laboratory measures and also to rank a range of helmets on a scale from 1 to 5 .
\end{abstract}

\section{Methods}

The determination of thermal and evaporative resistance was assessed on seven helmets, using a head manikin in a climatic chamber under $20^{\circ} \mathrm{C}, 40 \%$ rh and two wind speeds $\left(1,3\right.$ and $\left.15,0 \mathrm{~km} \cdot \mathrm{h}^{-1}\right)$. Four indicators $\left(\mathrm{Rc}_{\text {low speed }}\right.$, $\left.\mathrm{Rc}_{\text {high speed }}, \mathrm{Re}_{\text {low speed }}, \mathrm{Re}_{\text {high speed }}\right)$ were thus obtained.

In order to better understand the behaviour of the helmets during field tests, a specific questionnaire was created for 15 horse riders (from Gallop 3 to Gallop 7) to collect the subjective responses of four helmets, on a 9-points-scale (from not ventilated to very ventilated), after an intense exercise of 45 minutes undertaken at the Equestrian Centre of Roubaix.

\section{Results}

From the four indicators, $\mathrm{Rc}_{\text {low speed }}$ was found to be significantly correlated with ventilation of horse riding helmets. The general grading remained the same by selecting the

\footnotetext{
* Correspondence: matthieu.jolly@decathlon.com

${ }^{1}$ Thermal Affective and Laboratories, Decathlon SportsLab, Villeneuve d'Asca, France

Full list of author information is available at the end of the article
}

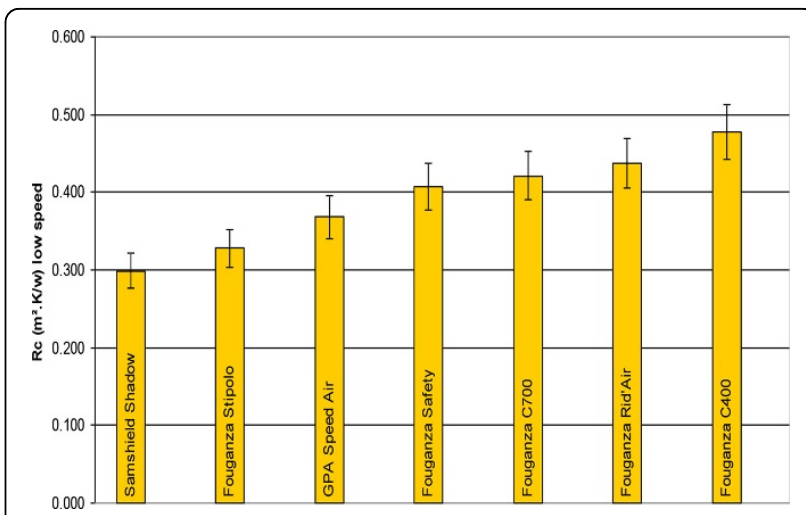

Figure 1

other indicators $R e_{\text {high speed }}, \mathrm{Re}_{\text {low speed }}$ and $R c_{\text {high speed }}$ but they are not more representative of the real use.

Thus we obtained the coefficients of the equation ventilation $=\alpha \cdot R c_{\text {low speed }}+\beta$, allowing us to rank our range of helmets.

\section{Discussion and conclusion}

The $0,179 \mathrm{~m}^{2} . \mathrm{K} . \mathrm{W}^{-1}$ range in the results can be explained by the no ventilation helmet (C400) compared to the ventilation oriented conception (Samshield, with channels, a way in and way out for the wind). The field results have highlighted the best choice for our indicator of ventilation, but with only four helmets tested in the field. In the future, results could be adjusted depending on the wind speed and the selection of head segments for the calculation. Brühwiler (2004) also showed that the inclination would be another area of investigation ${ }^{3}$. The test method will also lead to strong improvement in the conception of helmets regarding ventilation. 


\section{Authors' details}

'Thermal Affective and Laboratories, Decathlon SportsLab, Villeneuve d'Asca,

France. ${ }^{2}$ Fouganza, equestrian brand of Decathlon, Villeneuve d'Ascq, France.

Published: 14 September 2015

\section{References}

1. Taylor NA, Caldwell JN, Dyer R: The physiological demands of horseback mustering when wearing an equestrian helmet. Eur J Appl Physiol 2008, 104(2):289-296.

2. Bogerd CP, Rossi RM, Brüwiler PA: Thermal perception of ventilation changes in full-face motorcycle helmet_subject and manikin study. Ann Occup Hyg 2011, 55(2):192-201.

3. Brühwiler PA, Ducas $C$, Huber R, Bishop PA: Bicycle helmet ventilation and comfort angle dependence. Eur J Appl Physiol 2004, 92(6):698-701.

doi:10.1186/2046-7648-4-S1-A87

Cite this article as: Jolly et al: Ventilation of horse riding helmets: what is the connection between laboratory and field measurements? Extreme Physiology \& Medicine 2015 4(Suppl 1):A87.

\section{Submit your next manuscript to BioMed Central} and take full advantage of:

- Convenient online submission

- Thorough peer review

- No space constraints or color figure charges

- Immediate publication on acceptance

- Inclusion in PubMed, CAS, Scopus and Google Scholar

- Research which is freely available for redistribution

Submit your manuscript at www.biomedcentral.com/submit 